\title{
Sequence analysis of mtDNA COI gene and molecular Phylogeny of Parasitic Unionicolid Mites (Acari: Unionicolidae: Unionicola) in China
}

\author{
Jian Cheng ${ }^{1}$, Xin Huang ${ }^{2}$, Liangliang Huang ${ }^{2, *}$ and Chungen Wen ${ }^{3}$ \\ ${ }^{1}$ Preschool Education College of Shangrao, 334000 Shangrao, China \\ ${ }^{2}$ College of Environmental Science and Engineering, Guilin University of Technology, 541004Guilin, China \\ ${ }^{3}$ College of Life Science, Nanchang University, 330031 Nanchang, China
}

\begin{abstract}
A nucleotide sequence analysis of cytochrome oxidase I (COI) gene fragment from parasitic unionicolid mites is performed in this paper. The aligned nucleotide fragment is 664bp (including gaps) in length, including 374 conserved sites, 284 variable sites, 73 conversion sites, 51 transpose sites. The conversion sites are much higher than the transpose sites with a conversion transpose ratio (si/sv) of 1.4. The percentages of $\mathrm{A}+\mathrm{T}$ and $\mathrm{G}+\mathrm{C}$ are $64.6 \%$ and $35.4 \%$ in the nucleotide sequence which indicates a strong AT bias. From the sequence analysis of COI gene, the relationship between Unionicola chelata and Unionicola arcuate are the farthest among all the parasitic unionicolid mites while the relationship between Unionicola ischyropalpus and U.arcuata are the closest. Using U.crassipes as an outgroup, the phylogenetic trees are reconstructed with maximum likelihood(ML) and neighbor-joining(NJ) inferences (PAUP4.0b10 tool), and the results show that U.arcuata is the more evoluted speciesand Unionicola agilex might be the first separated from ancestral species.
\end{abstract}

\section{Introduction}

Most species of unionicolid mites camp parasitic life, their developmental processes are closely related to freshwater mussels, bivalves and sponges[1,2]. Currently, there are 209 species of unionicolid mites globally distributed. There are only 20 species of unionicolid mites recorded in China, which belong to 8 subgenera[3], such as U. arcuata, U. ypsilophora, U. chelate, U. agilex sp. nov. Morphological differences among species of parasitic unionicolid mites are comparatively minor, with taxonomic distinctions among most members of the taxon based on subtle differences in one or two morphological characters. In addition, because of their high productivity, short generation cycle and fast development progress, they can co-evolution with their host which results in morphological differences. Therefore, there exists a lot of arguments on parasitic unionicolid mites' taxon in the systems. In recent years, molecular marker techniques are widely used to identify approximate species and covert species[4].

The mitochondrial genome contains two ribosomal RNA (rRNA), 22 transport RNA (tRNA), and 13 genes that encode proteins. Because of their structural and functional differences, each gene region is also used to analyze phylogenetic relationships at various taxonomic levels, of which the cytochrome oxidase I (COI) gene is widely used to analyze phylogenetic relationships between species, taxonomic classifications, and geographic populations [5, 6]. Based on the mitochondrial COI gene, Elizabeth et al[7] studied the genetic structure and phylogeny of Eupodes minutus in the evolution of volcanic events and glacial events in the course of historical evolution. It was found that 11 different geographical location 57 samples of the genetic differences are large which concluded that volcanic and glacial events have a great impact on Eupodes minutus population. At present, only the RAPD[8] and $12 \mathrm{~S}$ rRNA[9] methods studied on the phylogenetic structure of Acarina have been reported. In this paper, mitochondrial DNA COI gene sequences of parasitic unionicolid mites collected from five lakes in the middle and lower reaches of the Yangtze River are compared to analyze the differences between intra-species and inter-specific in COI sequences. The phylogenetic tree was used to infer the relationships between intra-species and inter-species, Molecular phylogenetic relationships and geographic differences. Based on mitochondrial COI gene information to study the parasitic unionicolid mites evolution of the system to establish the basic data.

\section{Materials and methods}

\subsection{Biological materials}

Parasite unionicolid mites were collected from freshwater mussels of five lakes in the middle and lower reaches of the Yangtze River as shown in Tab. 1.

\footnotetext{
*Corresponding author: 1lhuang@glut.edu.cn
} 
Specimens were examined and classified under anatomy and microscopy according to the known species of Unionicola in China. Parasites unionicolid mites are cultured in water-containing Petri dishes for 2-3 days to remove debris that adhering to the body and then stored in $70 \%$ ethanol.

Table. 1 Sample exanimated of species, host and locality

\begin{tabular}{|c|c|c|c|}
\hline Species & host & Sampling locality & Code \\
\hline U. arcuata & Cristaria plicata & Taihu Lake, China & TGW \\
\hline U. arcuata & C. plicata & Poyang Lake, China & PGW \\
\hline U. arcuata & C. plicata & Honghu Lake, China & HGW \\
\hline U. arcuata & C. plicata & Dongting Lake, China & DGW \\
\hline U. arcuata & Anodonta woodia. pacifica & Poyang Lake, China & PYW \\
\hline U. arcuata & A. woodiana pacifica & Honghu Lake, China & HYW \\
\hline$U$. agilex & Cristaria plicata & Honghu Lake, China & HGJ \\
\hline U. agilex & A. woodiana pacifica & Dongting Lake, China & DYJ \\
\hline U. agilex & A. woodiana pacifica & Honghu Lake, China & HYJ \\
\hline U. ischyropalpus & C. plicata & Honghu Lake, China & HGM \\
\hline U. ypsilophora & A. woodiana woodiana & Chaohu Lake, China & CBY \\
\hline U. ypsilophora & A. woodiana woodiana & Taihu Lake, China & TBY \\
\hline U. ypsilophora & A. woodiana pacifica & Dongting Lake, China & DYY \\
\hline U. chelata & Cipangopaludina chinensis Gray & Chaohu Lake, China & CTA \\
\hline U. chelata & C. chinensis Gray & Taihu Lake, China & TTA \\
\hline U. chelata & C. chinensis Gray & Honghu Lake, China & HTA \\
\hline U. crassipes & ponds & Nanchang, China & WLQ \\
\hline
\end{tabular}

\subsection{DNA extraction}

DNA was prepared by crushing an individual mite with a plastic pestle in a $1.5 \mathrm{ml}$ micro-centrifuge tube containing $65 \mu \mathrm{L}$ extraction buffer $(200 \mu \mathrm{g} / \mathrm{ml}$ proteinase $\mathrm{K}, 0.1 \mathrm{M} \mathrm{NaCl}, 1 \mathrm{mM}$ EDTA, $10 \mathrm{mM}$ Tris- $\mathrm{HCl}, \mathrm{pH} 8.0$ ) at $56^{\circ} \mathrm{C}$. The reactions were incubated at $56^{\circ} \mathrm{C}$ for $2 \mathrm{~h}$ and terminated by heating at $95^{\circ} \mathrm{C}$ for $45 \mathrm{~s}$. Specimen debris was eliminated after centrifugation at $3000 \mathrm{~g}$ for $1 \mathrm{~min}$, and DNA in the supernatant fluid was subsequently stored at $-20^{\circ} \mathrm{C}$.

\subsection{PCR amplification and sequencing}

A 658 bp fragment was amplified from the COI gene of mitochondrial DNA of parasitic unionicolid mites by using universal primers[10]:

FCP: 5'-GGTCAACAAATCATAAAGATATTGG-3'

RCP: 5'-TAAACTTCAGGGTGACCAAAAAATCA-3'

The PCR reaction system consists of $2.5 \mu \mathrm{L} 10 \times \mathrm{PCR}$ Buffer, $2 \mu \mathrm{L}$ dNTPs $(2.5 \mathrm{mM}$ each), $0.3 \mu \mathrm{L}$ Taq DNA Polymerase $(5 \mathrm{U} / \mu \mathrm{L}, \mathrm{TaKaRa}), 1 \mu \mathrm{L}$ each of the upstream and downstream primers $(10 \mu \mathrm{M})$ and $5 \mu \mathrm{L}$ DNA template. Finally, we add sterile double distilled water and make the volume of reaction system $25 \mu \mathrm{L}$ (all the operations are carried out on the ice box). The PCR conditions followed by 40 cycles, including an initial denaturation step at $94^{\circ} \mathrm{C}$ for $5 \mathrm{~min}, 30 \mathrm{~s}$ for denaturation at $90^{\circ} \mathrm{C}, 1$ min for primer annealing at $48^{\circ} \mathrm{C}$ and $1 \mathrm{~min}$ for primer extension at $72^{\circ} \mathrm{C}$. A final extension step was carried out for $10 \mathrm{~min}$ at $72^{\circ} \mathrm{C}$. A $5 \mu \mathrm{L}$ volume of the reaction mixture was examined by $1 \%$ agarose gel electrophoresis followed by staining with ethidium bromide. The PCR products were purified through a PCR purification kit (Promega, Madison, WI, USA), cloned into plasmid pMD18-T vector using procedures and reagents provided by the manufacturer (Takara, Dalian, China), then sequenced with an Applied Biosystems ABI Prism 377 Automated DNA Sequencer (Sangon, Shanghai, China).

\subsection{Alignment and phylogenetic analysis}

Nucleotide sequences were aligned using the CLUSTAL-X1.83program (European Molecular Biology Laboratory, Heidelberg, Baden-Württemberg, Germany). The pairwise sequence divergences were computed using the MEGA 4.0 program (Arizona State University, Tempe, Arizona, USA) according to the Kimura 2-parameter (K2P) model.

Phylogenetic trees were constructed using maximum likelihood(ML) method and neighbor-joining(NJ) algorithm that implemented in PAUP 4.0b10 (University of Florida, Gainesville, Florida, USA). Bootstrap analyses were used to examine the robustness of the resulting bifurcations within the tree. To estimate the bootstrap support, a total of 1000 and 100 replicates were run for ML and NJ, respectively. Branches with bootstrap values larger than $70 \%$ were considered resolved.

\section{Results}

\subsection{DNA sequences}

The sequences of mtDNA-COI gene of each sample of parasitic unionicolid mites was $658-660 \mathrm{bp}$. The final sequence of the mtDNA-COI gene was registered in GenBank database with the accession numbers of FJ218003-FJ218018 and FJ524382. It was found that the aligned nucletide fragment is $664 \mathrm{bp}$ (including gap) in length, including 374 conserved sites, 284 variable sites, 73 conversion sites, 51 transpose sites, The conversion sites is higher than the transpose sites with a conversion transpose ratio $(\mathrm{si} / \mathrm{sv})$ of 1.4 . Accordingly, the 
percentages of $\mathrm{A}+\mathrm{T}$ and $\mathrm{G}+\mathrm{C}$ are $64.6 \%$ and $35.4 \%$ in the nucleotide sequence, showing a strong AT bias. The average genetic distance of parasitic unionicolid mites samples was 0.223 (Tab 2). The genetic distance between U.chelata and other parasitic mites varied greatly, among which the genetic difference between U.chelata and
U.arcuata was 0.305 , indicating that the genetic relationship between them was the farthest; There was the smallest genetic difference between U.ischyropalpus and U.chelata, with a difference of 0.170 , indicating that they are the most closely related.

Tab.2 Genetic distances among samples exanimated of parasitic unionicolid mites

\begin{tabular}{|c|c|c|c|c|c|c|c|c|c|c|c|c|c|c|c|}
\hline Species & 1 & 2 & 3 & 4 & 5 & 6 & 7 & 8 & 9 & 10 & 11 & 12 & 13 & 14 & 16 \\
\hline \multicolumn{16}{|l|}{ TGW (1) } \\
\hline \multicolumn{16}{|c|}{ DGW (2) 0.000} \\
\hline PGW（3） & 0.000 & 0.000 & & & & & & & & & & & & & \\
\hline $\mathrm{HGW}$ (4) & 0.002 & 0.002 & 0.002 & & & & & & & & & & & & \\
\hline PYW（5） & 0.005 & 0.005 & 0.005 & 0.006 & & & & & & & & & & & \\
\hline HYW (6) & 0.154 & 0.154 & 0.154 & 0.156 & 0.155 & & & & & & & & & & \\
\hline DYY (7) & 0.233 & 0.233 & 0.233 & 0.235 & 0.234 & 0.219 & & & & & & & & & \\
\hline DYJ（8） & 0.285 & 0.285 & 0.285 & 0.288 & 0.287 & 0.292 & 0.253 & & & & & & & & \\
\hline HYJ（9） & 0.283 & 0.283 & 0.283 & 0.285 & 0.285 & 0.289 & 0.251 & 0.002 & & & & & & & \\
\hline HGJ (10) & 0.278 & 0.278 & 0.278 & 0.280 & 0.280 & 0.272 & 0.266 & 0.159 & 0.161 & & & & & & \\
\hline CTA (11) & 0.295 & 0.295 & 0.295 & 0.298 & 0.297 & 0.285 & 0.265 & 0.253 & 0.253 & 0.235 & & & & & \\
\hline TTA (12) & 0.302 & 0.302 & 0.302 & 0.305 & 0.304 & 0.292 & 0.267 & 0.251 & 0.251 & 0.242 & 0.008 & & & & \\
\hline HTA (13) & 0.295 & 0.295 & 0.295 & 0.297 & 0.297 & 0.285 & 0.263 & 0.247 & 0.247 & 0.233 & 0.015 & 0.014 & & & \\
\hline $\begin{array}{c}\text { HGM } \\
(14)\end{array}$ & 0.270 & 0.270 & 0.270 & 0.268 & 0.272 & 0.270 & 0.238 & 0.228 & 0.226 & 0.183 & 0.173 & 0.172 & 0.170 & & \\
\hline CBY (15) & 0.254 & 0.254 & 0.254 & 0.254 & 0.260 & 0.271 & 0.258 & 0.230 & 0.230 & 0.236 & 0.240 & 0.242 & 0.240 & 0.230 & \\
\hline TBY (16) & 0.264 & 0.264 & 0.264 & 0.264 & 0.270 & 0.271 & 0.262 & 0.249 & 0.249 & 0.249 & 0.212 & 0.212 & 0.214 & 0.213 & 0.115 \\
\hline $\begin{array}{l}3.2 \text { Co } \\
\text { compos }\end{array}$ & $\begin{array}{l}\text { lon } u \\
\text { ition }\end{array}$ & $\begin{array}{l}\text { sage } \\
\text { analys }\end{array}$ & $\begin{array}{l}\text { freq } \\
\text { is }\end{array}$ & & & inc & cic & & $\begin{array}{l}\text { valin } \\
\text { positi } \\
\text { U.arc } \\
\text { e. The }\end{array}$ & $\begin{array}{l}\text { e }(\mathrm{V} \\
\text { on. Th } \\
\text { uata } \\
\text { U.yp }\end{array}$ & $\begin{array}{l}\mathrm{w} \\
\text { the } \\
\text { oph }\end{array}$ & $\begin{array}{l}\text { higl } \\
\text { lo pro } \\
\text { wood } \\
\text { in th }\end{array}$ & $\begin{array}{l}\text { er in } \\
\text { ine (Pr } \\
\text { ana po } \\
\text { A.wo }\end{array}$ & $\begin{array}{l}\text { the } \\
\text { o) in } \\
\text { cifice }\end{array}$ & $\begin{array}{l}\text { amino aci } \\
\text { he U.chelat } \\
\text { of Hongh }\end{array}$ \\
\hline $\begin{array}{l}\text { The freque } \\
\text { 3) and its } \\
\text { mites wer } \\
\text { results sho }\end{array}$ & $\begin{array}{l}\text { ency ot } \\
\text { amin }\end{array}$ & $\begin{array}{l}f \text { codor } \\
\text { o acid }\end{array}$ & $\begin{array}{l}\text { usag } \\
\text { (Tab. }\end{array}$ & $\mathrm{f} \mathrm{mt}$ & $\mathrm{NA}-\mathrm{C}$ & OI gen & $\begin{array}{l}\text { e (Tab. } \\
\text { hicolid } \\
\text { e. The }\end{array}$ & & $\begin{array}{l}\text { aohu } \\
\text { schyrof } \\
\text { itain ti } \\
\text { I gene }\end{array}$ & $\begin{array}{l}\text { Lake } \\
\text { palpus }\end{array}$ & id no & $\begin{array}{l}\text { t con } \\
\text {.plicat }\end{array}$ & $\begin{array}{l}\text { tain } \mathrm{h} \\
a \text { of } \mathrm{Hc} \\
\text { ecting } \\
\text { lo acid }\end{array}$ & $\begin{array}{l}\text { istidine } \\
\text { onghu I } \\
\text { the m } \\
\text { compos }\end{array}$ & $\begin{array}{l}\text { (His). The } \\
\text { Lake did not } \\
\text { iitochondrial } \\
\text { sition. }\end{array}$ \\
\hline
\end{tabular}
amino acids. Leucine(Leu), isoleucine (Ile), lysine (Lys),

Table 3 The codon usage frequency of parasitic unionicolid mites

\begin{tabular}{|c|c|c|c|c|c|c|c|}
\hline Codon & Usage frequency & Codon & $\begin{array}{c}\text { Usage } \\
\text { frequency }\end{array}$ & Codon & Usage frequency & Codon & $\begin{array}{l}\text { Usage } \\
\text { frequency }\end{array}$ \\
\hline UUU(F) & $2.4(0.49)$ & UCU(S) & $0.1(0.04)$ & UAU(Y) & $4.9(1.47)$ & UGU(C) & $5.6(1.80)$ \\
\hline UUC(F) & $7.6(1.51)$ & $\mathrm{UCC}(\mathrm{S})$ & $1.9(1.33)$ & $\mathrm{UAC}(\mathrm{Y})$ & $1.8(0.53)$ & $\mathrm{UGC}(\mathrm{C})$ & $0.6(0.20)$ \\
\hline UUA(L) & $15.4(1.86)$ & UCA(S) & $1.6(1.07)$ & $\mathrm{UAA}(*)$ & $8.6(1.27)$ & $\mathrm{UGA}(*)$ & $5.4(0.79)$ \\
\hline UUG(L) & $7.3(0.88)$ & UCG(S) & $0.7(0.47)$ & $\mathrm{UAG}\left({ }^{*}\right)$ & $6.4(0.94)$ & UGG(W) & $2.5(1.00)$ \\
\hline CUU(L) & $0.2(0.02)$ & CCU(P) & $0.0(0.00)$ & CAU(H) & $0.8(0.72)$ & CGU(R) & $1.6(0.83)$ \\
\hline CUC(L) & $5.1(0.62)$ & $\mathrm{CCC}(\mathrm{P})$ & $1.6(2.81)$ & $\mathrm{CAC}(\mathrm{H})$ & $1.4(1.28)$ & CGC(R) & $0.1(0.03)$ \\
\hline CUA(L) & $12.6(1.52)$ & $\mathrm{CCA}(\mathrm{P})$ & $0.4(0.76)$ & CAA(Q) & $5.8(1.11)$ & CGA(R) & $0.9(0.50)$ \\
\hline CUG(L) & $9.1(1.10)$ & $\mathrm{CCG}(\mathrm{P})$ & $0.3(0.43)$ & CAG(Q) & $4.6(0.89)$ & CGG(R) & $1.0(0.53)$ \\
\hline AUU(I) & $0.9(0.18)$ & $\operatorname{ACU}(\mathrm{T})$ & $0.0(0.00)$ & AAU(N) & $3.8(1.52)$ & AGU(S) & $2.5(1.71)$ \\
\hline AUC(I) & $7.7(1.45)$ & $\mathrm{ACC}(\mathrm{T})$ & $1.5(1.81)$ & $\mathrm{AAC}(\mathrm{N})$ & $1.2(0.47)$ & AGC(S) & $2.0(1.37)$ \\
\hline AUA(I) & $7.3(1.37)$ & $\operatorname{ACA}(\mathrm{T})$ & $1.4(1.66)$ & $\operatorname{AAA}(\mathrm{K})$ & $11.9(1.48)$ & AGA(R) & $5.5(2.92)$ \\
\hline AUG(M) & $3.4(1.00)$ & $\operatorname{ACG}(\mathrm{T})$ & $0.4(0.53)$ & $\operatorname{AAG}(\mathrm{K})$ & $4.2(0.52)$ & AGG(R) & $2.3(1.19)$ \\
\hline GUU(U) & $4.8(1.15)$ & GCU(A) & $1.0(1.31)$ & GAU(D) & $1.8(1.81)$ & GGU(G) & $1.8(0.67)$ \\
\hline GUC(U) & $2.0(0.48)$ & GCC(A) & $0.3(0.41)$ & GAC(D) & $0.2(0.19)$ & GGC(G) & $0.6(0.23)$ \\
\hline GUA(U) & $7.8(1.85)$ & $\mathrm{GCA}(\mathrm{A})$ & $1.2(1.55)$ & GAA(E) & $5.1(1.12)$ & GGA(G) & $3.6(1.33)$ \\
\hline GUG(U) & $2.2(0.52)$ & GCG(A) & $0.6(0.73)$ & GAG(E) & $4.0(0.88)$ & GGG(G) & $4.8(1.77)$ \\
\hline
\end{tabular}




\subsection{Phylogenetic analysis}

The phylogenetic tree was reconstructed using the maximum likelihood(ML) and the NJ algorithms (Figures 1 and 2). The topologies of the ML and NJ trees are basically the same. As shown by the phylogenetic tree, all species of parasitic unionicolid mites can be get together, U.agilex were located at the base of the phylogenetic tree independently with $99 \%$ and $100 \%$ confidence levels, respectively. U.ischyropalpus and U.chelata are gathered in the second branch; U.arcuata and U.ypsilophora are gathered in the third branch, and U.arcuata are located on the top of the branch. In addition, parasites from all the major lakes hosted within the same species of mussel mites are gathered in a small branch. From the ML tree in Fig. 1, we can see that the U.arcuata in C.plicata of Taihu Lake, Honghu Lake, Poyang Lake and Dongting Lake gather together, and the U.arcuata in A.woodiana pacifica of Poyang Lake and
Honghu Lake gather together. As all the U.arcuata parasites in different hosts are clustered together, we can conclude that the main lakes in the middle and lower reaches of the Yangtze River do not cause geographical isolation.

\section{Discussion}

The nucleotide sequences of the mitochondrial COI gene from parasitic unionicolid mites of different hosts and geographies are as rich in $\mathrm{A}$ and $\mathrm{T}$ as other Acarids[4]. This high AT content is a common feature of insect mitochondrial base composition[11]. Although the mechanism of high AT contents in mitochondria is unclear, it is known that the natural mutation process favors the formation of A and T, e.g. the conversion of guanine to O6-methylpurine by alkalization and mismatch with thymine, which results in the replacement

Tab.4 The amino acids composition of COI gene partial sequences of parasitic unionicolid mites

\begin{tabular}{ccccccccccccccccc}
\hline Phe & Gly & His & IIe & Lys & Leu & Met & Asn & Pro & Gln & Arg & Ser & Thr & Val & Trp & Tyr & Total \\
\hline 4.55 & 6.57 & 1.52 & 9.09 & 8.08 & 25.76 & 2.53 & 2.53 & 1.01 & 4.55 & 4.55 & 5.05 & 3.03 & 7.58 & 2.02 & 4.04 & 198 \\
4.55 & 6.57 & 1.52 & 9.09 & 8.08 & 25.76 & 2.53 & 2.53 & 1.01 & 4.55 & 4.55 & 5.05 & 3.03 & 7.58 & 2.02 & 4.04 & 198 \\
4.55 & 6.57 & 1.52 & 9.09 & 8.08 & 25.76 & 2.53 & 2.53 & 1.01 & 4.55 & 4.55 & 5.05 & 3.03 & 7.58 & 2.02 & 4.04 & 198 \\
4.55 & 6.57 & 1.52 & 9.09 & 8.08 & 25.25 & 2.53 & 2.53 & 1.01 & 4.55 & 4.55 & 5.56 & 3.03 & 7.58 & 2.02 & 4.04 & 198 \\
4.5 & 7 & 1.5 & 9 & 8.5 & 25.5 & 2.5 & 2.5 & 1 & 4.5 & 4.5 & 5 & 3 & 7 & 2 & 4.50 & 200 \\
4.1 & 4.1 & 1.03 & 10.77 & 10.77 & 26.15 & 1.03 & 3.08 & 0.00 & 1.54 & 8.72 & 5.64 & 0.51 & 11.79 & 1.54 & 2.05 & 195 \\
4.59 & 6.63 & 1.02 & 9.69 & 7.14 & 25 & 2.04 & 1.53 & 2.55 & 3.57 & 6.63 & 4.59 & 2.04 & 10.2 & 1.02 & 2.04 & 196 \\
4.62 & 6.15 & 0.51 & 5.64 & 3.59 & 23.59 & 1.54 & 2.56 & 3.08 & 6.15 & 8.21 & 5.64 & 2.05 & 8.21 & 1.54 & 2.05 & 195 \\
4.62 & 6.15 & 0.51 & 5.64 & 3.59 & 24.10 & 1.54 & 2.56 & 2.56 & 6.15 & 8.21 & 5.64 & 2.05 & 8.21 & 1.54 & 2.05 & 195 \\
5.64 & 6.15 & 2.05 & 7.69 & 5.64 & 26.15 & 2.05 & 1.03 & 1.54 & 5.13 & 7.69 & 5.64 & 1.03 & 7.18 & 1.03 & 1.54 & 195 \\
6.22 & 3.63 & 1.04 & 6.74 & 11.4 & 25.39 & 1.04 & 3.11 & 0 & 7.17 & 4.15 & 3.11 & 1.04 & 9.84 & 0.52 & 4.15 & 193 \\
6.22 & 3.63 & 1.04 & 6.74 & 10.88 & 25.39 & 1.04 & 3.11 & 0 & 7.17 & 4.66 & 3.11 & 1.04 & 9.84 & 0.52 & 3.63 & 193 \\
5.7 & 3.63 & 1.04 & 8.29 & 10.88 & 24.87 & 1.04 & 3.11 & 0 & 8.29 & 4.66 & 3.63 & 0.52 & 9.33 & 0.52 & 3.63 & 193 \\
5.7 & 2.59 & 2.07 & 10.36 & 11.4 & 26.42 & 1.04 & 4.15 & 0.52 & 4.66 & 5.70 & 2.59 & 0.52 & 6.22 & 0 & 3.63 & 193 \\
5.64 & 7.18 & 0 & 7.18 & 8.21 & 26.67 & 1.54 & 2.05 & 2.05 & 5.13 & 5.64 & 3.08 & 0.51 & 9.23 & 1.03 & 4.1 & 195 \\
6.15 & 4.62 & 0.51 & 5.64 & 7.69 & 25.64 & 1.54 & 2.05 & 1.54 & 6.67 & 5.64 & 3.08 & 0.51 & 9.74 & 1.03 & 4.62 & 195 \\
5.11 & 5.5 & 1.15 & 8.12 & 8.24 & 25.46 & 1.76 & 2.56 & 1.18 & 5.34 & 5.78 & 4.47 & 1.69 & 8.56 & 1.28 & 3.39 & 195.6 \\
\hline
\end{tabular}

of GC base pairs by AT base pairs[12].

At present, the species of water mites of the genus Acarina are all evolved from the ancestor mites of the subgenus Unionicolidae that are living freely, from the species of aquatic life to the parasitic life[13], Therefore, this study chose U.crassipes as an outer group to build phylogenetic tree. From the phylogenetic trees in Fig. 1 and Fig. 2, we can see that the same parasitic unionicolid mites from the same host in different lakes can all get together well. U.arcuata gather at the forefront of phylogenetic tree, farthest away from the outer group, while U.agilex located in the root of phylogenetic tree which is the nearest group from the outer group. According to the report of $\mathrm{Fu} \mathrm{J}[14]$, phylogenetic 


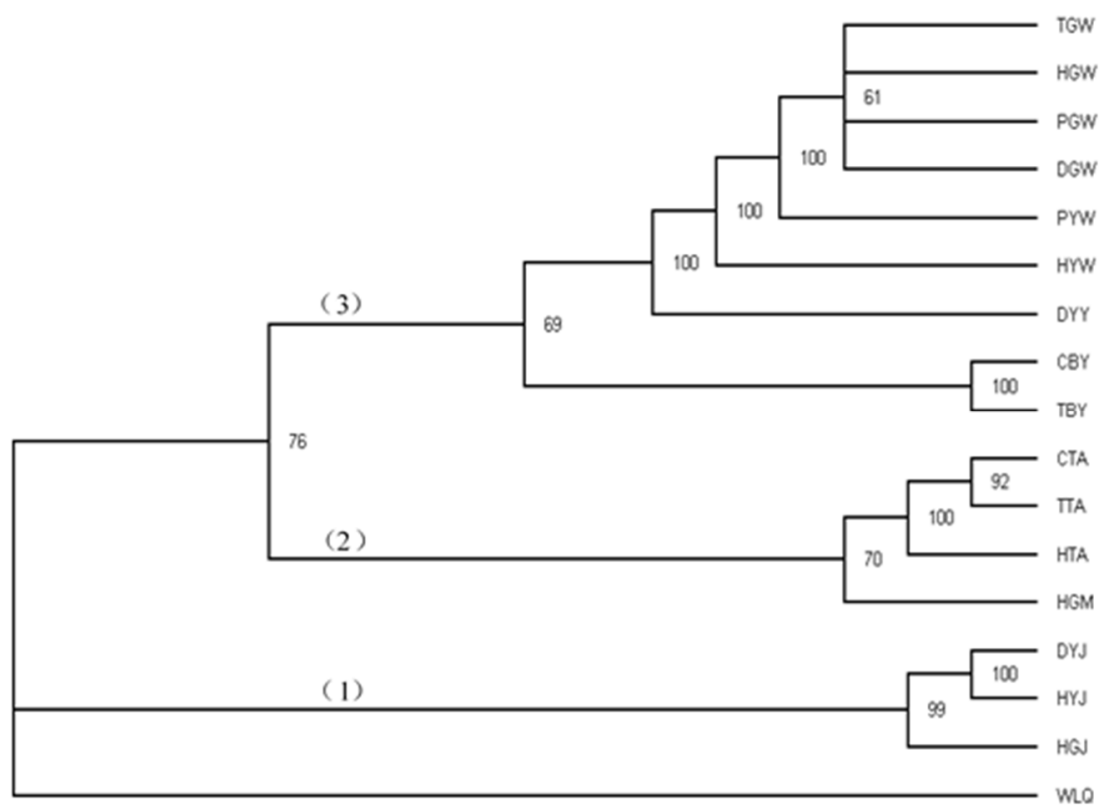

Fig. 1 Phylogenetic tree of parasitic unionicolid mites inferred from partial mitochondrial COI gene sequences using ML algorithm and Unionicola crassipes are employed as the outgroup (numbers at nodes are bootstrap values).

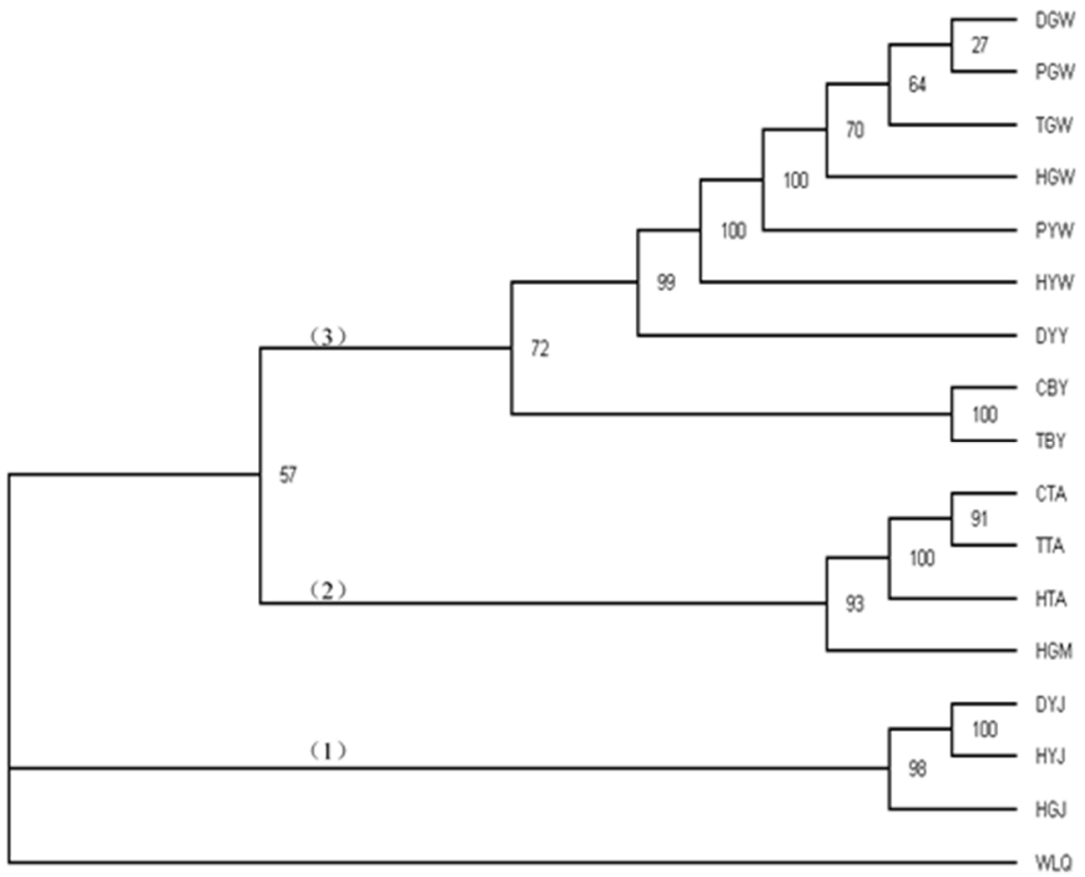

Fig. 2 Phylogenetic tree of parasitic unionicolid mites inferred from partial mitochondrial COI gene sequences using NJ and the Unionicola crassipes are employed as the outgroup (numbers at nodes are bootstrap values)

studies on 27 species of Coccinellids showed that (i) the Epilachninae which the first division from the base of the phylogenetic tree should be the ancestral group of the Coccinellidae, (ii) Scymninae was grouped with Chilocorinae, showing they had a close relationship. From this we infer that U.arcuata is relatively evolutionary species and U.agilex is relatively original species.

The host can provide the parasite habitat, food sources, etc., and some host immune defense measures will also exert some pressure on the parasite selection[15]. Long-term interaction between the parasite and its host forms a co-evolution phenomenon[16]. Phylogenetic tree showed that the same species of unionicolid mites parasitic in different hosts, they exist some differences. The sucking louse communities on the same genus of small mammal hosts showed a high similarity and were clustered into the same group; when the small mammal hosts were very close in the zoological taxonomy, the commumities of sucking lice on their body surface tend to be similar, the results indicated that there would be a synchronized evolutionary relationship between sucking lice and their small mammal hosts[17]. The seabird ticks are closely 
related to the hosts, Ixodes uriae is highly specific to different hosts, and the hosts have an important regulatory role on the Ixodes uriae populations[18]. Parasitic unionicolid mites have obvious selectivity and preference to their hosts and there also exist host specificities[2, 19]. There were significant differences in the allelic sites of U.poundsi and U.lasallei between different hosts, which may be related to the host specificity. Unionicolid mites parasitized in the host's microenvironment. After a long evolutionary process, the genetic material will change in order to better adapt to the host[20].

In this experiment, the molecular characteristics of the parasitic unionicolid mites DNA were found to be significantly related to their hosts. The results showed that there were some differences in the gene sequences of the same parasitic unionicolid mites in different hosts; For example, U.arcuata is divided into two branches, one from C.plicata and the other from A.woodiana pacifica. Therefore, we hypothesize that the unionicolid mites parasitize the hosts, their living environment is isolated, and there is a lack of gene exchange between the populations, thus generating genetic polymorphisms. Phylogenetic studies on the parasitic copepods of Ergasilidae and Lernaeidae show that the host not only affects the infection levels of parasitic copepods but also plays an important role in the formation of species[21]. Downes[22] concluded that the metamorphosis of unionicolid mites was largely influenced by the host. When a parasite moves from one host to another it will have different requirements on its physiological processes. It is not surprising that individuals undergo a genetic change after they switch hosts which is known as convergent evolution[23]. An original parasite can branch and evolve as the branch of the host germline develops[24]. Although fragmentation of the habitat can reduce population size and increase isolation, this indicates a significant impact on population genetic and quantitative changes[25]. Comparing with the Eriocheir sinensis from the Yellow River Estuary and Pearl River valley, the sequence of mitochondrial COI gene fragment was found to be basically the same[26]. Therefore, we infer that different lakes in the middle and lower reaches of the Yangtze River have less effect on the COI gene of Acaridae, while host specificity is the main factor affecting the gene variation.

\section{Acknowledgement}

This research was financially supported by a project (No. 30571434) of the National Natural Science Foundation of China, and in part by the project of the Scientific and Technological Education Department (GJJ09055), and the Natural Science Foundation (No. 0630122) of Jiangxi Province, China

\section{References}

1. C. Davids. Hydrobiologia. 41, 37-44(1973).

2. C. Wen, P. Nie and Z. Zhu. Dis Aquat Organ. 1-2, 123-127(2006).
3. M. F. Vidrine, D. Joubert, L. B. Thomas, A. E. Bogan, and W. X. Ping. Int J Acarol. 4, 389-392(2008).

4. B. R. Ernsting, D. D. Edwards, M. F. Vidrine, and H. Cun. Int J Acarol. 4, 403-407(2008).

5. O. Benabdelkrim Filali, M. Kabine, A. El Hamouchi, M. Lemrani, M. Debboun, and M. Sarih. Vector-Borne Zoonot. 9, 479-484(2018).

6. G. Ananthan and R. Murugan. Mitochondrial Dna A. 1, 121-125(2018).

7. E. Mortimer and B. J. V. Vuuren. Polar Biol. 4, p471-476(2007).

8. Y. Zhao and L. Wu. Parasitol Res. 6, 2395-2402(2012).

9. V. I. Evangelou, M. Bouga and G. T. Papadoulis. Int J Acarol. 7, 331-333(2016).

10. O. Folmer, M. Black, W. Hoeh, R. Lutz, and R. Vrijenhoek. Molecular marine biology and biotechnology. 5, 294(1994).

11. S. Chris, F. Francesco, B. Andrew, C. Bernie, L. Hong, and F. Paul. Ann Entomol Soc Am. 6, 6(1994).

12. J. J. Xie, L. X. Sun and Z. Y. Huang. Journal of Quanzhou Normal College. 2, 54-58(2001).

13. F. Vidrine Malcolm. Int J Acarol. 4, 233-243(1986).

14. J. Fu and Y. C. Zhang. Entomotaxonomia. 3, 179-186(2006).

15. A. M. Paterson and J. Banks. Int J Parasitol. 9, 1012-1022(2001).

16. J. P. Webster and C. M. Davies. Parasitology. Suppl, S41-S56(2001).

17. W. E. Feeney, J. A. Welbergen and N. E. Langmore. Annual Review of Ecology Evolution \& Systematics. 1, 227-246(2014).

18. K. D. McCoy, T. Boulinier, C. Tirard, and Y. Michalakis. J Evolution Biol. 3, 395-405(2001).

19. D. D. Edwards, R. Bogardus and N. Wilhite. Exp Appl Acarol. 12, 683-697(1998).

20. D. D. Edwards and M. Labhart. J Parasitol. 5, 1008-1011(2000).

21. C. Wedekind and A. Ruetschi. Evol Ecol Res. 8, 1031-1043(2000).

22. B. J. DOWNES. SYSTEMATIC ZOOLOGY. 2, 162-168(1990).

23. D. J. Rees, M. Dioli and L. R. Kirkendall. Mol Phylogenet Evol. 1, 131-142(2003).

24. D. R. Brooks. Syst Biol. 30, 229-249(1981).

25. A. G. Young and G. M. Clarke. Cambridge University Press. 19, 335-360(2000).

26. X. Kong, Z. Yu, Y. Liu, T. Gao, and Y. Wu. Journal of Ocean University of Qingdao. 31, 861-866(2001) 